\title{
畜産農家の環境意識と堆肥販売意向に関する要因分析
}

\author{
竹内 重吉 (日本学術振興会特別研究員 / 岡山大学) \\ 駄田井 久 (岡山大学大学院環境学研究科) \\ 佐藤 豊信（岡山大学）
}

\section{Analysis of Livestock Farmers' Environmental Consciousness and Sales Intention with Regard to Compost}

\author{
Shigeyoshi Takeuchi (JSPS Research Fellow/Okayama University) \\ Hisashi Datai (Graduate School of Environmental Science, Okayama University)
}

Toyonobu Satoh (Okayama University)

Developments in the field of livestock management in Japan have led to a change from the traditional methods of livestock management to a processed form of the same that depends on imported feed. This change has caused the superfluous generation of manure in farmlands, thus resulting in an environmental hazard. In order to solve the aforementioned problem, it is necessary to stop the prevalent scattering of the additional compost in the farmlands and to shift to an environment-friendly management system under which the additional compost is sold outside the farmlands.

The main indicators for the possible occurrence of the abovementioned shift to such a management

\section{1. はじめに}

我が国の音産経営に括いては, 輸入飼料に依存し た加工型畜産として発展してきた。 そのため，畜産 経営内農地に扔いて家畜排せつ物が過剩となり, こ れらに由来する畜産環境問題が発生している。 この 様な環境問題を解決するためには, 畜産経営内農地 への過剩な堆肥散布を中止し, これらの堆肥を畜産 経営外に販売する必要がある.

筆者他はこれまで, 岡山県笠岡湾干拓地の畜産農 家を対象に, 堆肥販売のマーケティング戦略を検討 した，その結果にもとづき，環境・経営的に成立可 能な環境保全型畜産経営モデルを構築した ${ }^{11}$.

しかし, この様な環境保全型経営への移行には, 環境に対する配慮の大きさや，堆肥販売への意向な would be the farmers' consciousness regarding the environmental problems resulting from the excess compost and their intention to sell this compost.

In this paper, I classify three subjective factors on the basis of the questionnaire administered to livestock farmers: their recognition of the environmental problems caused by them, their subjective evaluation of these environmental problems, and their intention to sell the compost generated on their farmlands. I analyze the measures needed for undertaking a shift to an environment-friendly form of livestock management on the basis of the farmers' responses with regard to these subjective factors.

ぞ畜産農家自身の意識（主観的要因）が関係してい ると考光られる。

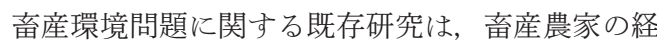
済的要因に着目したものが多く見られる。一方で, 畜産農家の主観的要因に着目したものは少ない ${ }^{2)}$.

また，現地の水質・土塨調査結果などの情報提供 は, 農家意識に影響を与えると考学らる。しかし， この様な情報提供が農家意識へ及ぼす効果を分析し たものはあまり見られない。

そこで本稿では「繰り返しアンケート調査」をもと に, 農家意識に関係する以下の諸点を明らかにする. まず，1畜産農家の環境問題に対する認識度（自ら の経営が及ぼしている環境への影響を，どの程度認 識しているのか)，次に(2)環境に対する主観的な評価 
(環境問題の解決に向けて，どの程度の負担を受け入 れるのか)，そして(3)堆肥販売に対する意向（どのよ らな堆肥販売体系を希望するのか), の 3 点である.

また，アンケート調査と同時に農家への情報提供 を行い，情報提供前後の農家意識の変化を見る。 そ の結果にもとづき，情報提供が農家意識へ及ぼす効 果を明らかにし, 主観的要因の視点から環境保全型 経営への移行に向けた対策を検討する.

\section{2. 対象地域の概要}

笠岡湾干拓地の全農地面積は約 860 ha であり, そ の内訳は，畜産部門：約 180 ha, 耕種部門 : 約 130 ha, 園芸部門 : 約 170 ha，粗飼料基地 : 約 380 ha となって いる. 現在，干拓地内では 6 戸の肥育農家により約 3,300 頭，11 戸の酪農家により約 2,400 頭の牛が飼 育されて沶り, 畜産部門全体で生産される堆肥は約 23,380 t/年である.

現在, 堆肥は畜産農家の農地（以下，畜産自作地 とする）へ散布，戻し堆肥として利用等，約 $76 \%$ が畜産経営内で利用されている. 自治体が管理す る粗飼料基地の牧草・景観作物生産への利用が約 $14 \%$, 干拓地内の耕種・園芸農家への販売量は約 $1 \%$, 干拓地外への販売量も約 $9 \%$ であり, 畜産経 営外への利用は少ない.

水質・土䁃調査の結果から, 畜産自作地付近の水 路では, 窒素・リン酸濃度が環境目標水準の約 5 倍 から 13 倍も高い事が明らかになっている3). その主 要因として，畜産自作地へ過剰に残留した肥料養分 が流出し，水路の水質へ影響を及ぼしていることが 指摘されている. 環境改善のためには, 畜産自作地 への堆肥散布の中止に加光, 約 $12,000 \mathrm{t} /$ 年 (現在
の約 5 倍）を畜産経営外へ販売する必要がある ${ }^{4)}$.

\section{3.「繰り返しアンケート調査」の概要}

本稿では，干拓地内の畜産農家を対象とし，畜産 農家への情報提供を取り入れた「繰り返しアンケ一 ト調査」を実施した。2 009 年 9 月に実施し、サン プル数は 10 戸である（酪農家 7 戸, 肥育農家 3 戸). 図1へ「繰り返しアンケート調査」の流れを示した.

まず, 1 回目のアンケートにより, 畜産農家の環 境に対する意識や，堆肥の販売意向などを明らかに する. 次に 1 回目の情報提供として, 堆肥の施肥基 準や干拓地の水質状況など，「環境問題に関する情 報」について説明を行ら。再度，2回目のアンケ一 トで 1 回目と同じ項目を質問し，これらの情報提供 が農家の意識へもたらす効果を明らかにする，2回 目の情報提供では，耕種農家の堆肥需要や，堆肥の 販売戦略など,「堆肥販売に関する情報」を説明する. そして，3回目のアンケートで，再度 1 回目の項目 を質問することにより，これらの情報提供の効果を 明らかにする。

提供する情報は対象地域の分析結果を用い，詳細 な数值データを添付した. これらの情報提供の効果 を明らかにすることが, 本アンケートの特徵である。

\section{4. アンケート結果}

\section{（1）回答者の属性}

まず，回答者の属性を表 1 に示す，飼養頭数から いずれも大規模な経営が多く，回答者の年齢は 20 代 から 70 代までと幅広い。堆肥の主な利用方法は， (1) 農地へ散布, (2)戻し堆肥へ利用, (3)共同堆肥舎へ搬出, (4)経営外へ販売,に分けられる ${ }^{5)}$. 堆肥の利用状況は,

\section{表 1. 回答者の属性}

\begin{tabular}{|c|c|c|c|c|c|c|c|c|c|c|}
\hline & \multirow{2}{*}{ 類型 } & \multirow{2}{*}{$\begin{array}{l}\text { 飼養 } \\
\text { 頭数 }\end{array}$} & \multirow{2}{*}{\begin{tabular}{|l|} 
回答者 \\
の年代
\end{tabular}} & \multicolumn{4}{|c|}{ 堆肥の利用状況 } & \multirow{2}{*}{\begin{tabular}{|c|} 
農地への堆肥 \\
散布量の推計值 \\
\end{tabular}} & \multirow{2}{*}{$\begin{array}{c}\text { 過剰散布 } \\
\text { の程度 }\end{array}$} & \multirow{2}{*}{$\begin{array}{l}\text { 農家の } \\
\text { 表記 }\end{array}$} \\
\hline & & & & 農地へ散布 & 戻し堆肥へ利用 & 共同堆肥舎へ搬出 & 経営外へ販売 & & & \\
\hline $\mathrm{A}$ & 酪農 & 140 頭 & 60 代 & $50 \%$ & $9 \%$ & $40 \%$ & $1 \%$ & $4.5 \mathrm{t} / 10 \mathrm{a}$ & $\triangle$ & $\mathrm{A} \triangle$ \\
\hline $\mathrm{B}$ & 酪農 & 404 頭 & 60 代 & $10 \%$ & $40 \%$ & $50 \%$ & $\times$ & $3 \mathrm{t} / 10 \mathrm{a}$ & 0 & $\mathrm{~B} \bigcirc$ \\
\hline $\mathrm{C}$ & 酪農 & 405 頭 & 70 代 & $90 \%$ & $\times$ & $10 \%$ & $x$ & $21 \mathrm{t} / 10 \mathrm{a}$ & $\times$ & $\mathrm{C} \times$ \\
\hline $\mathrm{D}$ & 酪農 & 430 頭 & 30 代 & $10 \%$ & $70 \%$ & $15 \%$ & $5 \%$ & $3 t / 10 a$ & 0 & $\mathrm{D} \bigcirc$ \\
\hline $\mathrm{E}$ & 酪農 & 365 頭 & 20 代 & $50 \%$ & $20 \%$ & $25 \%$ & $5 \%$ & $9 \mathrm{t} / 10 \mathrm{a}$ & $x$ & $\mathrm{E} \times$ \\
\hline $\mathrm{F}$ & 酪農 & 122 頭 & 30 代 & $60 \%$ & $30 \%$ & $5 \%$ & $5 \%$ & $4.5 \mathrm{t} / 10 \mathrm{a}$ & $\triangle$ & $\mathrm{F} \triangle$ \\
\hline $\mathrm{G}$ & 酪農 & 71 頭 & 50 代 & $50 \%$ & $50 \%$ & $x$ & $x$ & $7 \mathrm{t} / 10 \mathrm{a}$ & $x$ & $\mathrm{G} \times$ \\
\hline $\mathrm{H}$ & 肥育 & 465 頭 & 30 代 & $\times$ & $10 \%$ & $10 \%$ & $80 \%$ & $0 \mathrm{t} / 10 \mathrm{a}$ & 0 & $\mathrm{H} \bigcirc$ \\
\hline $\mathrm{I}$ & 肥育 & 429 頭 & 40 代 & $x$ & $\times$ & $80 \%$ & $20 \%$ & $0 \mathrm{t} / 10 \mathrm{a}$ & 0 & $\mathrm{I} \bigcirc$ \\
\hline $\mathrm{J}$ & 肥育 & 577 頭 & 40 代 & $30 \%$ & $x$ & $70 \%$ & $x$ & $5 \mathrm{t} / 10 \mathrm{a}$ & $\triangle$ & $\mathrm{J} \triangle$ \\
\hline
\end{tabular}


酪農家と肥育農家で違いが見られる。酪農家は農地 へ散布・戻し堆肥へ利用する割合が高く, 肥育農家 は共同堆肥舎へ搬出・経営外へ販売の割合が高い.

各農家の飼養頭数と, 堆肥の利用状況, 農地面積 から, 農地への堆肥散布量を推計した。 岡山県飼料

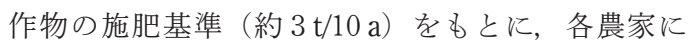
おける堆肥過剰散布の程度を明らかにした. 表 1 に, 基準值以下を $\bigcirc$, 基準值の 2 倍以内を $\triangle$, 基準值の 2 倍以上を×，で示した。 以下，各農家の表記はこ れらの記号と合わせて表 1 右端の通りとする.

\section{(2) 1 回目のアンケート結果}

1 回目のアンケート結果を表 2 に示す. 堆肥の生 産量を把握している農家は 3 戸，農地への堆肥散布 量を把握している農家は 4 戸であった. これらの農 家が回答した堆肥散布量は, 農家 $\mathrm{B} \bigcirc: 3 \mathrm{t} / 10 \mathrm{a}, \mathrm{J} \triangle$ : $2 \mathrm{t} / 10 \mathrm{a}, \mathrm{G} \times: 4 \mathrm{t} / 10 \mathrm{a}, \mathrm{C} \times: 5 \mathrm{t} / 10 \mathrm{a}$ であった. 表 1 の「堆肥散布量の推計值」と比較すると, 農家 $\mathrm{B} \bigcirc$ を除いては実際の散布量より少なく見積もっている. 更に, 現在の散布量が環境に対して「適切」と認識 している農家は，5戸（農家 $\mathrm{B} \bigcirc ・ \mathrm{~A} \triangle \cdot \mathrm{J} \triangle \cdot \mathrm{C} \times \bullet$ $\mathrm{E} \times)$ であり, そのらち農家 $\mathrm{B} \bigcirc$ 以外は過剒散布を行っ ている農家であった，農地に打ける土䁃中の肥料養 分濃度を把握している農家は 6 戸であった。

7 戸の農家が，現在の干拓地内水路の水質は「環 境目標より悪い水準である」と認識していた. しかし， 水質の水準を正確に把握していたのは，そのらち 4 戸であった．堆肥散布が水質へ及ぼす影響について は, 多くの農家が「その影響度は小さい」と回答した.

7 戸の農家が直接・間接的に近隣住民の苦情を把 握していた. そして半数の農家が「堆肥の利用」に 関して近隣住民を意識していた.

「堆肥販売の意向がある」と回答した農家は半数 であった. しかし, 堆肥販売に対するコスト負担に 関しては，8戸の農家が「コストは負担したくない」 と回答した。具体的な環境改善への対応策として, 半数の農家は「頭数削減を行わず, 堆肥販売で対応 したい」と回答し，半数の農家は「どちらも行いた くない」と回答した.

\section{（3） 1 回目の情報提供}

1 回目のアンケート結果から, (1)畜産農家は堆肥 の生産量や散布量を正確に把握していない, (2)堆肥 散布の環境への影響度は小さいと認識, (3)干拓地内 水路の水質状況を正確に把握していない, (4)環境改

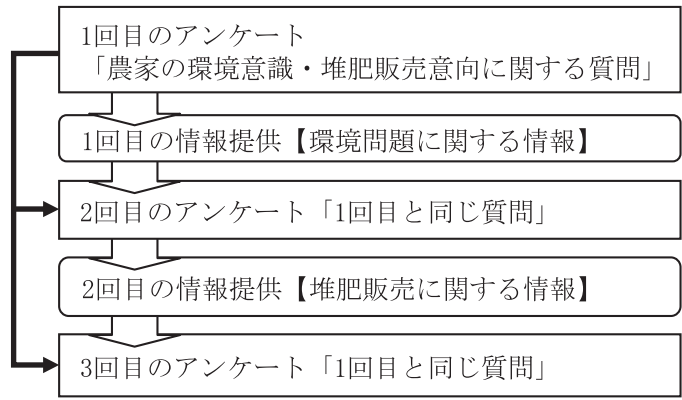

図 1.「繰り返しアンケート調査」の流れ

表 2. 1 回目のアンケート結果

\begin{tabular}{|c|c|c|}
\hline 質問項目 & 回答 & 戸数 \\
\hline \multirow{2}{*}{ 問 1 堆肥の生産量を把握していますか? } & 把握している & 3 \\
\hline & わからない & 7 \\
\hline \multirow{2}{*}{ 問 2 堆肥の散布量を把握していますか？ } & 把握している & 4 \\
\hline & わからない & 4 \\
\hline \multirow{2}{*}{$\begin{array}{l}\text { 問 } 3 \text { 現在の散布量は, 環境に対して「適 } \\
\text { 切」と思いますか? }\end{array}$} & 適切 & 5 \\
\hline & 多い & 3 \\
\hline \multirow{2}{*}{$\begin{array}{l}\text { 問 } 4 \text { 農地に扣ける土㙵中の肥料養分濃度 } \\
\text { を把握していますか? }\end{array}$} & 把握している & 6 \\
\hline & わからない & 2 \\
\hline \multirow{3}{*}{$\begin{array}{l}\text { 問 } 5 \text { 干拓地内水路の水質は, 環境目標水 } \\
\text { 準と比較して, との程度の水準であると思 } \\
\text { いますか? }\end{array}$} & わからない & 2 \\
\hline & 環境目標より低い & 1 \\
\hline & 環境目標より高い & 7 \\
\hline \multirow{4}{*}{$\begin{array}{l}\text { 問 } 6 \text { 農地への堆肥散布が, どの程度, 水 } \\
\text { 質へ影響を及ぼしていると思いますか？ } \\
\text { (影響度の水準 : } 0 \% \text { 100\%) }\end{array}$} & $10 \%$ & 4 \\
\hline & $25 \%$ & 4 \\
\hline & $75 \%$ & 1 \\
\hline & $90 \%$ & 1 \\
\hline \multirow{3}{*}{$\begin{array}{l}\text { 問 } 7 \text { 「堆肥の利用」や「水質問題」に関 } \\
\text { して, 近隣住民の苦情を聞いたことはあり } \\
\text { ますか? }\end{array}$} & 知らない & 3 \\
\hline & 間接的に, 聞いた & 6 \\
\hline & 直接, 苦情を受けた & 1 \\
\hline \multirow{2}{*}{$\begin{array}{l}\text { 問 } 8 \text { 「堆肥の利用」に関して, 近隣住民 } \\
\text { を意識しますか? }\end{array}$} & 意識しない & 5 \\
\hline & 意識する & 5 \\
\hline \multirow{2}{*}{ 問 9 堆肥の販売意向はありますか？ } & ない & 5 \\
\hline & ある & 5 \\
\hline \multirow{3}{*}{$\begin{array}{l}\text { 問 } 10 \text { 堆肥販売によって, 環境污染が } 100 \% \\
\text { 改善できるなら，堆肥販売にいくらまでコ } \\
\text { ストを負担してもよいと思いますか? }\end{array}$} & 0 円 $/ \mathrm{t}$ & 8 \\
\hline & 500 円/t & 1 \\
\hline & 2,000 円 $/ \mathrm{t}$ & 1 \\
\hline \multirow{2}{*}{$\begin{array}{l}\text { 問 } 11 \text { 環境改善に向けた対応として,「頭 } \\
\text { 数削減」「堆肥販売」のどちらが望ましいで } \\
\text { すか? (水準:頭数削減 } \bigcirc \%, \text { 堆肥販売 } \bigcirc \%)\end{array}$} & 堆肥販売のみで対応 & 5 \\
\hline & どちらも行いたくない & 5 \\
\hline \multicolumn{3}{|c|}{ 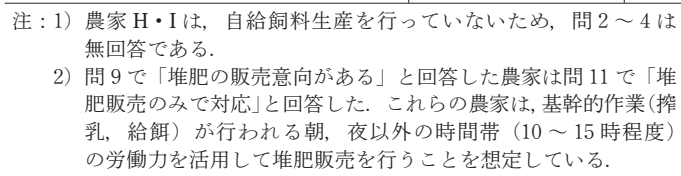 } \\
\hline
\end{tabular}

善へのコスト負担意識は低い，ことが明らかとなっ た。つまり，畜産農家は干拓地の環境問題に対する 認識が十分ではないと考兄られる。

そこで，「環境問題に関する情報提供」として以 下 4 項目の説明を行った.

1）岡山県飼料作物の施肥基準は, 約 $3 \mathrm{t} / 10 \mathrm{a}$ である.

2）堆肥を連年施用する場合，前年度の有機態養分 
表 3. 2 回目と 3 回目のアンケート結果

\begin{tabular}{|c|c|c|c|c|c|c|c|c|c|}
\hline & \multicolumn{2}{|c|}{$\begin{array}{l}\text { 問 6* 農地への堆肥散布が, ぞ } \\
\text { の程度, 水質へ影響を及ぼし } \\
\text { ていると思いますか（影響 } \\
\text { 度の水準 : } 0 \% \text { 100\%) }\end{array}$} & \multicolumn{2}{|c|}{$\begin{array}{l}\text { 問 8*今後，堆肥を利用する時，近隣 } \\
\text { 住民を意識しょうと思いますか？ } \\
\text { （意識の向上度を } 5 \text { 段階で評価） }\end{array}$} & \multicolumn{3}{|c|}{$\begin{array}{c}\text { 問 9* 堆肥の販売意欲は向上しましたか？ } \\
\text { (意欲の向上度を } 5 \text { 段階で評価） }\end{array}$} & \multicolumn{2}{|c|}{$\begin{array}{l}\text { 問 } 10 * \text { 問 } 10 \text { で提示して頂いた } \\
\text { 堆肥眅売へのコスト負担額へ, } \\
\text { 更に上乗せをしてもよいと思 } \\
\text { いますか? }\end{array}$} \\
\hline & 1 回目 & 2 回目 & 1 回目 & 2 回目 & 1 回目 & 2 回目 & 3 回目 & 1 回目 & 2 回目 \\
\hline $\mathrm{H} \bigcirc$ & $90 \%$ & & 意識する & & ある & & & 2,000 円 $/ \mathrm{t}$ & \\
\hline $\mathrm{I} O$ & $10 \%$ & $50 \%$ & 意識しない & 今までより意識する $(+3)$ & ある & 向上した $(+3)$ & 更に向上した $(+3)$ & 0 円 $/ \mathrm{t}$ & \\
\hline $\mathrm{B} \bigcirc$ & $25 \%$ & & 意識しない & & ない & & & 0 円 $/ \mathrm{t}$ & \\
\hline $\mathrm{D} \bigcirc$ & $10 \%$ & $25 \%$ & 意識する & & ない & & & 0 円 $/ \mathrm{t}$ & \\
\hline $\mathrm{A} \triangle$ & $25 \%$ & $50 \%$ & 意識する & 今までより意識する $(+5)$ & ある & 向上した $(+4)$ & 更に向上した $(+3)$ & 500 円 $/ \mathrm{t}$ & \\
\hline $\mathrm{F} \triangle$ & $25 \%$ & $75 \%$ & 意識する & 今までより意識する $(+2)$ & ある & & 向上した $(+4)$ & 0 円 $/ \mathrm{t}$ & \\
\hline $\mathrm{J} \triangle$ & $25 \%$ & & 意識する & & ない & & & 0 円 $/ \mathrm{t}$ & \\
\hline $\mathrm{G} \times$ & $10 \%$ & & 意識しない & & ない & & & 0 円 $/ \mathrm{t}$ & \\
\hline $\mathrm{E} \times$ & $75 \%$ & & 意識しない & & ある & & & 0 円 $/ \mathrm{t}$ & \\
\hline $\mathrm{C} \times$ & $10 \%$ & & 意識しない & & ない & & & 0 円/t & \\
\hline
\end{tabular}

注：1）対象農家の配列は，過㮃散布を行っていない農家：○から，過㮃散布の程度が大きい農家：×の順となっている。

2）空欄は，「変化なし」を意味する。

が土壤中に残留している，そのため化学肥料と 併用し，堆肥の投入量を減らす必要がある ${ }^{6}$.

3）過剩肥料養分が引き起こす問題として，水質 污染，作物の生育障害，家畜への悪影響，な どがある.

4）干拓地内水路の水質は, 窒素・リン酸濃度が 環境目標水準の約 5 倍から 13 倍高く，その主 要因として畜産自作地から流出した窒素・リ ン酸が原因である。

\section{（4）2 回目のアンケート結果}

以上の「環境問題に関する情報提供」を踏まえた 上で, 再度同じ項目を質問した(表 3)。その結果,「堆 肥散布が水質へ及ぼす影響度」は, 4 戸の農家が「よ り影響度が大きい」と回答した。「近隣住民への意識」 は, 3 戸の農家が「今までより意識する」と回答した. 「堆肥の販売意向」は，2 戸の農家が「堆肥の販売意 欲が向上した」と回答した. 最後に,「堆肥販売へ のコスト負担」については, すべての農家が「1回 目の提示金額と变わらない」と回答した。

\section{（5）2 回目の情報提供}

2 回目のアンケート結果から, 1 回目の情報提供は, 過剩散布を行っていない農家：○や，過剩散布の程 度が小さい農家： $\triangle$ には効果があるが，過剩散布の 程度が大きい農家：×には効果がない結果となった。

そこで，次に「堆肥販売に関する情報提供」とし て以下 3 項目の説明を行った ${ }^{7}$.

1）環境改善に必要となる堆肥販売量は, 干拓地 全体で約 $12,000 \mathrm{t} /$ 年（現在の約 5 倍）である.

2）干拓地周辺の耕種農家に抢ける堆肥ニーズ
3）畜産農家の堆肥販売戦略

\section{（6）3 回目のアンケート結果}

「堆肥販売に関する情報提供」を踏まえた上で, 再度問 9 を質問した．結果として, 3 戸の農家が「販 売意欲が更に向上した」と回答した（表 3)。また， 提供した 3 つの情報の中で最も重要な情報として は, 2)「耕種農家の堆肥ニーズ」といら回答が多く, この情報があ孔ば，3）「堆肥販売戦略」は予測可能 という意見が多かった。しかし，堆肥の過剩散布を

\section{表 4. 農家が希望する堆肥販売モデル}

\begin{tabular}{|c|c|c|c|c|}
\hline & 一モデル i & モモデル ii & モデルiii & モデル iv \\
\hline 販売主体 & $\begin{array}{c}\text { 農家間で協 } \\
\text { 力が必要 } \\
\end{array}$ & $\begin{array}{c}50 \% \text { は農家間で協 } \\
\text { 力, } 50 \% \text { は個人で対応 }\end{array}$ & $\begin{array}{c}\text { 個人対応 } \\
\text { が主 }\end{array}$ & $\begin{array}{c}\text { 外部組織 } \\
\text { へ委託 }\end{array}$ \\
\hline 販売収入 & 多い & 中程度 & 少ない & なし \\
\hline 労働力 & $\begin{array}{l}\text { 冬場に } \\
\text { 多く必要 }\end{array}$ & 年間通じて中程度 & 少ない & 必要なし \\
\hline $\begin{array}{l}\text { 個人対応 } \\
\text { の困難度 } \\
\end{array}$ & $\begin{array}{l}\star \star \star \\
\star \star\end{array}$ & $\begin{array}{l}\star \star \star \star ~ \\
\text { 市坊 }\end{array}$ & 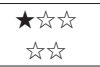 & 论坛访 \\
\hline
\end{tabular}

問 12 上記に示した 4 つの眅売モデルについて 4 点満占で得点を

\begin{tabular}{c|c|c|c|c}
\multicolumn{5}{|c}{ 付けてさい. (同得点可) } \\
\hline $\mathrm{H} \bigcirc$ & 3 & 4 & 2 & 1 \\
\hline $\mathrm{I} \bigcirc$ & 3 & 4 & 2 & 1 \\
\hline $\mathrm{A} \triangle$ & 2 & 3 & 4 & 1 \\
\hline $\mathrm{F} \triangle$ & 2 & 4 & 3 & 1 \\
\hline $\mathrm{E} \times$ & 2 & 3 & 4 & 1 \\
\hline 平均得点 & 2.4 & 3.6 & 3 & 1 \\
\hline
\end{tabular}

注 : 1) 提示した販売モデルは, 2 回目の情報提供「畜産農家の堆肥販売 戦略」の 3 モデルに, 堆肥販売を外部組織へ委託するモデルiv を加え質問した。

2) モデル iv は畜産農家の労働負担, 販売コスト負担がない反面, 販売収入は組織の運営に利用し，農家には還元しないことを想 定している.

3）堆肥の販売収入とは, (堆肥販売の売上一販売コスト) であり, 販売コストは輸送費，散布費，袋詰め費，労働費 $(1,000$ 円 $/ \mathrm{h})$ などである. 農家自身が販売作業を行ら場合,「販売収入十労賃 が得られることを説明した。 
行い，販売意向がない農家 $\mathrm{J} \triangle \cdot \mathrm{G} \times ・ \mathrm{C} \times$ に対し ては，効果がなかった。

最後に, 堆肥の販売意向がある農家を対象に, 農 家が希望する堆肥販売モデルを明らかにした（表 4).

最も評価が高かったのは, 農家間協力の程度・販 売収入・労働力がすべて中程度のモデル ii であった. また, 最も評価が低かったのは堆肥販売を外部組織 へ委託するモデルivであった ${ }^{8)}$.

\section{5.「堆肥の販売意向」にもとづく農家の分類}

以上の結果から，各農家に打ける堆肥の販売意向 にもとづき，農家を 3 つのイイプに分類した。

まず，堆肥の適正量散布を行い（過剒散布を行って いない), 販売意向がない農家 $\mathrm{B} \bigcirc, \mathrm{D} \bigcirc$ タイプ $\mathrm{I}$ とする. これらの農家は環境問題を引き起こしていな い. 次に堆肥の過剒散布の有無に関わらず販売意向が ある農家 $\mathrm{H} \bigcirc, \mathrm{I} \bigcirc, \mathrm{A} \triangle, \mathrm{F} \triangle, \mathrm{E} \times$ をタイプ II する. 最後に, 堆肥の過剰散布を行っており販売意向 がない農家 $\mathrm{J} \triangle, \mathrm{G} \times ， \mathrm{C} \times$ をタイプIII とする.

これらのタイプと農家の経営条件との関係を整理 する ${ }^{9}$. 酪農家の $\mathrm{F} \triangle$ (タイプ II ) や $\mathrm{G} \times$ （タイ プIII）は小規模で家族労働力を中心とした経営体で あり, 自給飼料は牧草生産を行っている. 一方, 酪 農家 $\mathrm{B} \bigcirc \cdot \mathrm{D} \bigcirc$ (タイプ I ) $\mathrm{A} \triangle \bullet \mathrm{E} \times$ (タイプ II ), $\mathrm{C} \times$ （タイプ III） は大規模で雇用労働力を中心とし た経営体である. 自給飼料は共同でトウモロコシ生 産を行い，同じ給慨体系を採用している.

肥育農家 $\mathrm{H} \bigcirc \cdot \mathrm{I} \bigcirc$ (タイプ II ) $\mathrm{J} \triangle$ （タイプ III ） は，3戸とも大規模で雇用労働力を中心とした経営 体であり，経営条件に大きな差異は見られない.

以上の様に，同じ経営条件でも堆肥の販売意向は 異なる.つまり, 販売意向には個々の経営主の主観 的な意識が強く関係しているものと考えられる ${ }^{10)}$.

\section{6. 環境保全型経営への移行に向けた対策}

最後に, 分類タイプごとに環境保全型経営への移 行に向けた対策を検討する.

\section{（1）タイプ II：堆肥の販売意向がある農家の場合}

タイプ Iの農家は，「環境問題」「堆肥販売」に関 する情報提供によって, 農家の環境意識と堆肥販売 意欲を向上させることが可能となる. この様に，こ のタイプの農家は対象地域の分析結果にもとづく, 具体的な情報提供により環境保全型経営へ移行でき
る可能性がある. 特に重要な情報は「耕種農家の堆 肥ニーズに関する情報」であった.

しかし, 農家の堆肥販売に対するコスト負担意識 は低く, 堆肥販売が経済的にも成立する（堆肥販売 による赤字が発生しない）ことが必要となる. 具体 的な販売体系としては，50\%を農家間で協力し，50\% は個人で対応する販売モデルへの評価が高かった。

\section{（2）タイプIII：堆肥の過剰散布を行い, 販売意向が ない農家の場合}

堆肥の過剰散布を行い，販売意向がないタイプIII の農家に抮いては，2 回の情報提供はいずれも効果 がなかった.この要因として，「堆肥販売を行らイ ンセンティブ（堆肥販売に対する主観的なコスト評 価)」の問題がある.

農家は，堆肥の利用行動を「農地への散布」から 「経営外への販売」へ移行することによって, (1)堆 肥販売への労働投入から，飼養牛管理から得られる 所得が減少, (2)化学肥料の購入費用が増加, (3)堆肥 販売先の開拓に要するコストが発生する。一方で, (4)堆肥の販売収入による所得増加, (5)環境問題の改 善, などのメリットもある.

しかし,タイプIIIの農家は環境意識が低く, (5)「堆 肥販売による環境問題の改善」から得られる効用は 小さいと考えられる ${ }^{11)}$. 今回, 提示した堆肥販売モ デルの中で，販売収入が最大となるのは，モデル i の約 5,300 円/t であった.つまりタイプIIIの農家に おける, 堆肥販売を行ら主観的なコスト評価額は, 約 5,300 円/t 以上であると考えられる.

以上の点を踏まえて，タイプIIIの農家が堆肥販売 を行らインセンティブを高める方策を考察する.

まずは, メリットを増加させる方策として，「堆 肥の販売収入」が約 5,300 円/ $\mathrm{t}$ 以上得られる販売方 策が必要となる。具体的には，耕種農家の堆肥需要 を考慮すると「袋詰めの販売，袋詰めの輸送販売」 があげられる ${ }^{12)}$. 次に,「堆肥販売による環境問題 の改善」から得られる効用に関しては，「家畜排せ つ物法」の見直しを検討し, 堆肥の利用過程に関し ても明確な規制を定める必要がある.これによって, 農家の環境意識を高めることが重要である.

一方，デメリットを減少させる方策として，「化 学肥料の購入費用」を抑えることがあげられる。対 象地域の農地では，長期間にわたる堆肥の連年施用 により, 肥料養分が過利に蓄積している. そのため, 
化学肥料の投入量を減少させても, 現在と同等の収 量が得られる可能性が高い ${ }^{13)}$. そのため, 現地での 試験栽培にもとづく実証的データを提供し, 環境を 基準とした施肥量を推進する必要がある。

\section{7. おわりに}

本稿では畜産農家への情報提供を取り入れた「繰 り返しアンケート調査」を実施し, 農家の環境意識 や堆肥販売意向を明らかにした。そして，それらの 情報提供が農家の意識へもたらす効果を検討した。

結果として, 畜産農家は環境問題に関する情報を 十分に認識していなかった，そして「環境問題」「堆 肥販売」に関寸る情報提供は, 農家の環境意識と堆 肥販売意欲を向上させることが明らかとなった．こ のことから農家への情報提供は，低コストで，かつ 有効な対策であるといえる.

堆肥の販売意向がある農家の具体的な販売体系と しては, 農家間協力による輸送販売と, 個人対応に よる畜産農家の庭先販売を組み合わせることが望ま しい, 一方, 堆肥の過剰散布を行い, 販売意向がな い農家においては，今回提示した情報提供だけでは 不十分であった。 そのため, これらの農家において は「堆肥販売のインセンティブを高める方策」が必 要である.

具体的な対策として，「販売意向がある農家」が 干拓地全体の堆肥販売をマネージメントする事が考 えられる，そのためには，次の 2 点が必要となる。

(1)肥料低投入の飼料生産を行い, 環境に負荷を与 える余利堆肥は, 全量を強制的に干拓地内の共同堆 肥舎へ収集する。(2)共同堆肥舎に収集した余唾堆肥 は, 「販売意向がある農家」が協力して労働力・販 売コストを負担し販売する. 販売収入は出役時間等 の負担に応じた配分を行う。

[付記］本稿は, 文部科学省科学研究費補助金(特 別研究員奨励費）による研究成果の一部である.

注 1）文献 [5] を参照されたい。

2）畜産農家の経済的要因に着目した研究として, 文献 [1]，[2]，[3]，[4] があげられる. 一方，主観的 要因に着目した研究として文献 [7] があげられる.

3）文献 [8] を参照.

4）堆肥の利用状況や, 堆肥販売量の算出方法につい ては，文献 [5] を参照されたい。

5）共同堆肥舎への搬出量は，各農家の出資金に応じ
て決められている. 搬出された堆肥は, 粗飼料基 地での牧草・景観作物生産等へ利用されている.

6）詳細は文献 [6] を参照されたい.

7）本稿で提供した情報は, 筆者が対象地域にて実施 してきた研究結果にもとついている.「干拓地周辺 の耕種農家に打ける堆肥二ーズ」は, 文献 [5]の p. 44「表 $1 」$ にとづいて説明を行った.「畜産農 家の堆肥販売戦略」は文献 [5] の p. 46「表 2」に もとづき, 堆肥の販売収入, 販売に必要となる労 働時間等を乳・肉用牛 100 頭当たりに換算し, 説 明を行った。

8）この要因として表 2注 2)より, 堆肥販売を行ら 労働力が飼養牛管理を行う労働力と競合しないこ とがあげられる。そのため「堆肥販売によって販 売収入十労賃を得たい」といら農家の選好から， モデルivは低く評価されたと考えられる.

9）本稿に打ける「経営条件」とは, 飼養頭数, 労働 条件, 自給飼料の生産体系などを意味する.

10）ただし，同じ経営条件でも表 2 注 2）から，タイ プ II の農家はその他の農家より労働力に余裕があ ることがらかがえる．この点については，今後の 課題としたい.

11）これらの農家の環境意識が低い要因として,「堆肥 化処理に対する農家意識」の問題がある. 農家か らは「家畜排せつ物法に従って, 処理施設を整備し, ふん尿の堆肥化処理を行っている. そのため, 堆 肥化処理を行えば環境污染は発生しない」という 意見が多かった。

12）耕種農家の堆肥需要については文献 [5] を参照.

13）肥料低投入の飼料生産に関しては文献 [6] を参照.

\section{引用文献}

［1］樋口昭則・三宅俊輔・澤岻直哉「環境負荷を考 慮した経営計画モデルの作成」、2005 年度日本 農業経済学会論文集』(2005), pp. 339-346.

[2]井上憲一・藤栄剛「個別酪農家における堆肥 供給行動の規定要因」, 『農業経営研究』第 112 号 (2002), pp. 53-56.

[3] 井上憲一・藤栄剛「堆肥供給組織による運搬 散布サービスの提供条件に関する考察」, 『農 業経営研究』第 133 号 (2007), pp. 12-24.

[4] 佐藤豊信「家畜粪尿堆肥化促進政策の経済分 析」『農業経済研究』第 74 巻第 3 号 (2002), pp. 123-132.

[5] 竹内重吉・駄田井久・佐藤豊信「環境保全型 畜産経営確立方策と堆肥販売戦略」, 『農林業 問題研究』第 174 号 (2009), pp. 42-47.

[6] 竹内重吉・佐藤豊信・駄田井久「肥料養分の 動態を考慮した環境保全型畜産経営モデルの 構築」, 『農林業問題研究』, 第 171 号 (2008), pp. $45-49$.

[7] 長命洋佑・揖斐隆之・仙田徹志・森佳子・広 岡博之「肉用牛経営の個別属性や経営意識が 家畜排泄物の処理・利用に及ぼす影響」，『農 林業問題研究』第 166 号 (2007), pp. 51-56.

[8] 梅谷真慈『笠岡湾干拓地内の水質及び畑地土 壤の概況調査』, 岡山大学環境理工学部卒業論 文 (2009) 